\title{
MAPPING AND PROTECTING THE INTELLECTUAL PROPERTY RIGHT IN THE FIELD OF THE TRADITIONAL BATIK DESIGN OF TIRTOMOYO AS THE CULTURAL HERITAGE AND ITS DEVELOPMENT BASED ON THE LOCAL GENIUS IN THE CREATIVE INDRUSTRIAL ERA.
}

\author{
Sarwono \\ Faculty of Literature and Art, Sebelas Maret University \\ Email: sarwono@staff.uns.ac.id
}

\begin{abstract}
In order to provide the protection to the "traditional batik art knowledge" in Tirtomoyo, Wonogiri, the local government policy rests on the potensial of art, commerce, services, education, tourism and sports.Here, it can be drawn the real purpose, that is to develop, to conserve, and to protect the traditional knowledge as the heritage and cultural expression, especially the traditional knowledge. In this case, the Intellectual Property Right protection and its all varieties should be applied on the traditional intellectual art. However, it has not yet manifested the regional regulation on the Intellectual Property Right, especially the protection to the traditional knowledge. There has not been confirmation about what institutions will be responsible or what kind of agencies will be involved in providing the protection to the traditional knowledge, like the batik art, dance art, and others, so that they don't seem loose accountability in handling it. The policy on the Intellectual Property Right, especially the one related to the traditional knowledge, is still partial or supplement. The Industry and Trade Department of Wonogiri regency, which handles the micro and medium industry field and is not related directly to the batik handicraft industry, has planned to make a program of batik handicraft industry as the regional superior.
\end{abstract}

Key words: Intellectual Property Right, Traditional knowledge, Batik Art.

\section{A. INTRODUCTION}

The art work, for Javanese society, is not a new and strange thing in the cultural living, because this kind of art has been considered as a part of life and it cannot be separated from the daily life. Art, especially the traditional textile design, has been admitted for its existence as a culture system in the symbol forms which are complicated, full of value 
related to the religion (Igoe, Elaine,2010: 3). This can be seen in the traditional ceremony activities carried out by the society by making in use the cloth in the form of the batik art.

The art work, as the handicraft of the supporting society, becomes the inspiration resource that can be endless when its value is delved and developed. The more the work is studied, the more wonderful the content is, wondering its aesthetics and symbolic value that are implied implicitly and explicitly in the art work (Laird, Melissa, 2011: 2). The realization culture which is realized in the handicraft work is the batik art which does not only exist in Java, but it also exists in almost all over Indonesia with different names, but it uses the same media and it has been lasting for a long time and it is passed on from generation to the other. Therefore, the art is also called as the culture art that actually has cosmopolitan and universal characteristics. So, the batik handicraft art can appear anytime, anywhere, as long as the human being still exists. This art work placed itself in the society culture treasury since a long time ago, and from generation to other generation it has become the society intellectual art, which is now known as the traditional knowledge.

WIPO forms the Global Intellectual Property issues Division (Global Issues Division) in the year 1997 in order to identify the problems that can affect interestingly to the system of the dominant Issue of Intellectual Property Right related to the protecting the traditional knowledge as one of the forms of intellectual activity in the industrial, scientific, literary or artistic fields. The activities done by this division are, among others, sending Facts - Finding Missions (FFMs), which results that:

-the traditional knowledge has been known widely and most of them are related to the belief systems;

-the traditional knowledge, which is owned by the society collectively, becomes the perspective of culture value and a part of medium of a community's tradition in the society;

-the traditional knowledge becomes the understanding that is not stagnant or static, but something that is dynamic and is developing in the society context.

-the protection to the traditional knowledge is also important in order to protect the individual's honor and community in the society; and 
- the Intellectual Property Right approach can give a protection to the traditional knowledge that is possible to be protected by the Intellectual Property Right, like the patent right, the creation right, and the industrial design, and the brand mark ( AgusSardjono, 2006,: 18, 19).

The batik art also contains, besides the beauty, ethic lesson (doctrine) in the form of visual and symbolic appearance of the life which is basically able to guide people to the perfectness and the genuine own personality, considering that the art is the realization of soul in the living that always creates action and reaction and it continuously finds the wise and good problem solving in accordance to the culture that has been formed. The art itself is a part of the entire expression of the society's culture that is as the art of the traditional knowledge. This also becomes the result of the human being's thought that has been begun a long time ago and its development becomes the intellectual property. By doing so, it appears the protection problem and its development in the society. In line with the activities of the society economic, in which the traditional art can be related to the activity of creative economic, so the possessiveness and the economic activity become the parts that cannot be separated from the global economic activity, considering the Intellectual Property Right contains the sides of the Morale Right and Economic Right.

Indonesia has to obey the agreement of TRIPs, because Indonesia is a WTO member and has to pass the legalization product on the Intellectual Property Right. The regulation in the field of the Intellectual property Right includes patent right, creation right, brand mark, industrial design, composition design of united circuit, and others have been adapted to the system of Indonesia Law as the result of the globalization. Those problems, willy-nilly, Indonesia has to follow the WTO agreement, so there should be the entire (full) adaptation on the regulation (law) in the field of Intellectual Property Right. The tradition art, in this case the batik traditional art that includes in the "traditional knowledge", is necessary to get the protection. The potential kind of Intellectual Property Right that is related to the art of tradition batik handicraft in Tirtomoyo, Wonogiri Regency, in this research is necessary to study in order to get an accurately clear juridical-conceptual depiction to give protection, and it is added the government commitment from either the Central or Regional governments ( Surakarta and its 
surrounding including Tirtomoyo, Wonogiri). This problem is very important due to the globalization era, where the value inside the Intellectual Property Right is really becoming the capitalist culture, on the other hand the Indonesian society owns the culture value itself in facing the global era.

Confirming the traditional batik art of Tirtomoyo society in the art work either traditional or new creation is the prove of the culture quality, so that increasing the creativity in the art field is necessary to be built in order to gain the benefit, it is not only based on the culture but also economic and politic for the society and it needs Intellectual Property Right protection. The reward for the artisans as the creators must be done and supported for the sake of the art development and to stimulate the society's creativity, and in the whole it is as the way to develop the society culture, and it is also as the development realization in Indonesia.

According to Eddy Damian (1999: 20): In realizing the conducive climate for increasing the spirit or willingness to arise the man's intellectual ability, it is necessary to raise a need that is a law protection, the need for the law protection is actually common. It becomes common when someone wants his rights of treasure he owns are admitted, respected, and can be held by him from other people's acting that contrasts to his right, doesn't it?

\section{B. RESEARCH METHODS}

Based on the problem studied, the research metode used in this study is the single case study. The single case study is a poled case study that focuses on several probabilities that have been determined before the researcher enters the field of study. Related to the research, the law is seen from the reality, it is not seen as the law norms. Therefore, the type of the research here is the one about mapping and protecting the traditional batik of Tirtomoyo related to the Intellectual Property Right.

The data resource is in the form of the batik art work of Tirtomoyo, Wonogiri. The informants consist of; batik artisans, either professional, academical, or the ones who understand about it, the experts who know the batik handicraft field,the people who are involved in making traditional batik in Tirtomoyo, Wonogiri, the archieves and 
documents and notations gained from many parties that can support the research. The technique used to collect the data is "open-ended interview" to search the subject's opinion on many things that is useful as the basic to present the data and its analises. The indepth interview can be done at the time and context that are considered being accurate (indepth interviewing).

The observation can be done directly or it is sometimes called as partisipative observation. In this observation, the researcher is involved in the role of developing the tradition batik design in Tirtomoyo, Wonogiri. The document and the archieve are both important data ressourses, too, it means that in the qualitative research especially when the research aims based on the background or many kinds of events happened long long ago and related much to the condition of nowadays events being studied.

Considering that it is a qualitatif study, therefore the data taken are characterized as "purposive sampling" or they are called as "criterion based selection". In order to increase the data validity in this study, it is used the triangulation data, so the data validity can be guaranteed

There are three main components that must be done correctly, that is the data reduction, data presentation, and conclusion or verivication. This analysis process is done to make the three main components united and it is done flowingly, so that this analysis model is often called as Flow Model of Analysis (Sutopo, HB, 2002: 101 - 104).

\section{DISCUSSION}

\section{Expression of the Culture Result in the Art of Traditional Batik Handicraft.}

The development of the batik cloth motive in Tirtomoyo, Wonogiri, up to now is synchronized to the market demand by keeping the motive characteristic in accordance to the design owned. Basically, the batik motives are made based on the idea resource of flora motive shape and geometrical shape with the various color composition, while in the fauna shape (animal realm), it is often presented in the unity form of batik pattern, and it is up to now still being kept. When it is seen at a glance that the batik motives in Tirtomoyo, Wonogiri, and its surrounding, up to now show the similarity, because the motive elements are similar. However, when it is observed carefully, in fact, the 
combination of the motive shape arrangement shows that there are differentiations. These differentiations happen because each craftsman has his own personality in accordance to his instinct, and it is adapted to the market need. From this point, the batik motive in Tirtomoyo, Wonogiri, and its surrounding, still keeps the classical batik motive which is full of symbolic value in the Javanese society, it also has many various motive forms, but it is still close to it and in rhythm with it entirely.

The development of the traditional batik cloth plays an important role in the usage. A long time ago, batik was used as an instrument (means) in the tradition ceremony and others. But along with the time and era shifts, the special use of it begins to change gradually and become to be multifunctional.This change is caused by the craftsman who becomes commercial, so that the batik cloth in Tirtomoyo in usage has become the economically commercial goods.

The Javanese culture cannot be separated from the philosophical values, either the spiritual or mindset. In many kinds of discussions of the Javanese spirit culture, it is called "Kejawen" (Suseno, 2001: 11 - 15). While the Javanese culture elements can include the literature, means of livelihood system, relative system, permanent pattern and its architecture, ceremony system, and its art, too. The central emphasis.which forms the background of Kejawenis called "Ngilmu", therefore the Kejawen knowledge cango through out its narrow environment to a general characteristic and universal (Holt in Soedarsono, 2000: 155). Though it is located in a narrow and specific place, that is Java, the culture can go up in the live and the life of man's nature.Having the rightness and perfectness purposes included in the Javanese culture that has philosophical characteristic, it exists the symbolism value that arises caused by the contact existence between the human being with the micro-cosmos and macro-cosmos, between the lives of inner self and the outer world. The Javanese culture, when it is seen from the spiritual point of view, contains the attempt to make the people have glorious and holy morals in all of their spiritual attitude and the holy character. The glorious morals and the spiritual attitude are the values that have a close relationship with the lives of the inner self and the outer world. Those values also arise due to the universal relationship between the human being and the God. (Buchari S., 1995: 2 - 5). 
From this point of view, the Javanese culture can also be seen that there is the balance between the people's inner self interacting with the nature and the Great Creator supported by intellectual activity (logic) in the "ngelmu" subject. The inner self, human being's super ritual, and intellectuality connect to the Great Creator. Therefore, the three of them are always related closely. This balance can be seen from their art works, among others is the puppet art and its stories that all contain the philosophical values included in their symbols. The objective is that all of the human's actions are intended to find the balance between the human and the nature, and to find the live perfectness in their lives (Mulder, 1996: 16 - 19)

The symbols become the direct expose of the ideas. In these symbols, of course, there is the heterogeneous unification (harmony) between the spontaneous idea and the one that is revealed by the spirit. This unification is not only built by the opinion, but it is also built by all of the deepest feeling lives and its manifestation spontaneously, in another word expressively. As the visual realization exposed directly from the idea and containing the live value of the artist's feeling, so the symbol is the unification.In the art field, the symbol is realized in the art work (Langer, 1962). The symbolizm is the culture mark which is used well in the art field or others, especially to give a special mark on the thing or by suggesting trough out the sense immaginations of the thing that cannot be seen by senses. According to Read's opinion, it is stated that symbolism can be in the form of the art work which its supporting elements are depicting the value analogy of a certain character that represents an abstract idea. The value of abstract idea will shape the unifaction or the quality relation gestalt, the strength, and gradation (Whiteheat, AN.,1928, Read, 1970: 121 - 130).

The art work of classical batik contains and fullfil the above elements, because the classical batik art is created in the quality uniformation, strength and gradation at that time, that is as the art thing to legitimate the position and the existence of the palace as the authority (Soedarmono, 1990: 10). While the motive type and its usage, according to Kalinggo Honggodipuro (2002) are mentioned as follows:

The Parang motive is the batik motive which has a special feature in the form of rock where in the middle of both rock motives it exists the element of mlinjon motive. 
This motive element differentiates the Parang motive and Lereng motive. TheParangmotive, viewed from the making process and naming on Parang motive, can be concluded that there are some concepts:

The Javanese society understands that in the belief form, the king as the Nurbuah, meaning that souls of Javanese king, will become the gods in the paradise, on the contrary, the gods can reincarnate to the king or other knights. Therefore the traditional custom done by the king (including wearing Parang Barong motive) is manifested in the gods' clothing in the Javanese leather puppet, Surakarta version.

The Javanese society considers that the unliving matters have the magic power, because inside of which the soul of their incestor stays. The magic power can be used by people to reach the goodness or badness. In the traditonal batik realm, that concept always accompanies in many kinds of things of their lives.

The belief that there is a magic power in the things, like the chreese (curiga) and other things, can be seen in the concept of making Parang motives, for examples; Parang Curiga, Parang Kusuma, Parang Kembang, etc. All of these are intended that there is a hidden expectation, that is the magic power of the mentioned thing, so the user (person) dan reach the objective wanted.

The usage of Kawung motive, or the man who has the right to wear it, is only the kingdom servants ( the beloved servants who have close relationship with the king and his family). The servants meant here are the low servants (emban, panakawan, the followers of the knights). The Kawung motive is also used by the person who has a high rank (position), the palace punggawa (Tumenggung) in the palace scope.

The motive usage ofSidomukti, Sidomulyo, Sidoluhur orSidoasih, in the Javanese traditional ceremony in Surakarta and its surounding (including Wonogiri) is always used by couples of bridegrooms, either male or female. The motive usage, in this case, is intended that there is an expectation meaning of the bride and groom in order to cross their household live and be able to socialize and adabt in their society. 
In the traditional ceremony of the Javanese wedding in Surakarta and its surrounding (including Wonogiri), the traditional motive, like Sidomukti, is used by the couple of the bride and the bridegroom in the "Pangeran" dressmaking, and it is not in the "basahan" bride and bridegroom dressmaking, because in the basahan dressmaking it is used a long cloth in the form of dodot with Semen Rama motive or Alas-alasan motive.

The Truntum batik motive, used as one of the traditional dressmaking in the Javanese society scope in Surakarta, is also manifested by the visual realization of the society's mindset. In creating the art work and the batik art specifically, the Javanese society has the purpose that is not based on the material purpose or physic which only has visual aestetic, but it is based on the "worshipping feeling" or worship to the great Creator. Besides the mentioned purpose, the Javanese society comprehends that the art work or the result of their culture is not clearly presented, but it is made based on the disguise concept or shadow that always contains "pasemon” or proverb.

The usage of Truntum batik motive in the Javanese traditional ceremony in Surakarta and its surrounding (including Tirtomoyo, Wonogiri) is always used by the parent couples of the bride, both male or female. This is intended that in this motive there is an expectation meaning of the parents in guiding their children to manage the household live and socialize and adabt in their society.

The ceplok batik motive is related to the kejawen belief. Motif batik ceplok berkaitan dengan kepercayaan kejawen. The basic of this understanding is the concept of authority which is believed that the authority will appear from the universe, besides from the human's authority.

The ceplok batik motive symbolizes that the King is the symbol of the world authority. The King is the means to give the divine revelation which is realized in giving the level rank (position) to his people. The King is also the protector through the regulation passed by.

The authority, among the human being, has the understanding meaning of the king authority to his people, inspiring by the ceplok form in which there is a central point 
located exactly in the middle of the main ornament. The four elliptical shapes existing in the ceplok motive represents as the symbolism of the people who are always surrounding and protecting the king.

The second type is the motive with the main ornament consisting of plants, meru, bird or lar-laran and animal arranged in harmony, but it is not in accordance to the geometric fields, and therefore it is called "semenan" batik motieve; e. g.semen rama, semen wijaya kusuma, gunung lar, bledag, sekar jagad, ukel, cuwiri, wahyu tumurun, gringsing, semen prabu, semen gendhong, semen nagaraja, babon angrem, etc.

The third type is the batik motive called "boketan" term, where the field placement of the batik motive for its ornament is not the same or continue. The motive located in one side field full of various ornaments is in accordance to the craftsman's creation in every region in Surakarta area and its surrounding.

The symbolic meaning consisting the traditional batik motive in the custom of Javanese ceremony in Surakarta area, as consisting in the motives of kawung ceplok, sidomukti, sido luhur, sido mulyo, wahyu tumurun, semen rama, wijaya kusumaWahyu Tumurun, Peksi Huk, Babon Angrem, Glebag Cuwiri, Parang Gapit Glebag Seruni, Parang Sondher,Parang Kesit Barong, Ole-ole andSapanti Nata; while the ones that includes the developed motive and the new craetions, among others are Buket Pakis, Imo Krendo, Gabah Sinawur, Anggur Sawunggaling, Jembatan Emas, Cohung Kraton, andRadityo Puspitoand others have symbolic meanings according to the usage in the Javanese tradition ceremony in Surakarta area and its surrounding. The symbolism actually contains the value of Javanese philosophy which is formed according to the religious-magic cultural frame. The development of the traditional batik motive in Tirtomoyo is also based on the idea resource from the region environment as the specific feature, for examples; Sandang Pangan, Catleya, Pring Sedapur, Seruni, Api Revolusi orSmara Dahana, Lereng Api Revolusi Gringsing, andMerak.TheLereng ApiRevolusi motive is the literary work of Surakarta Classic Batik, e. g. Lereng pattern, combined with Lidah Api. TheSandang Pangan andApi Revolusi, Smara Dahana motives represent the visualization inspired by the event and daily experiences. 


\section{The Globalization and Protection to the Intellectual Property Right}

The globalization era causes various changes in every live line, these changes are influenced by the science development, technology mainly the information technology, and the political change occuring in every line and society stratum. As a result for this, the change of living arangement in the society is formed. People only used to think about morale aspect, but now the economic aspect becomes an important part. So, to think, to plan, to act, and to make a decision in the economic field nowadays is influenced very much by the concepts of thinking, planning, and acting globally (Sri Redjeki Hartono, 2007:70). The globalization has three requirements, they are the technology, the regulation based on the International economic wisdom system, and the business role. This concept influences the countries, especially the developing countries that become to be put at edge. According to Clare Short that there are at least three main characteristics of the globalization process. The globalization makes the world face shape change fast and influences many countries, especially the developing countries that are still thrown out in the economic globalization (2005:460).

The globalization shows that there are globally products and technology, corporation, and industries. The globalization can be seen through the existence of the economic globally, because the economic system work is not limited by the country borders. The rest is the national borders, like the people that forms a nation with country. The main asset that must be owned by a country is the citizen's expertise and concept and the human resource (Nasikun, 2000: 32). The last aspect is very important to support the success of Indonesia in entering (facing) the global era.From this point of view, the encreasing quality related to the skill and morale intergrity for the business agent, the government bureaucracy apparatus, the society, and the apparatus of the law upholder is continuelly attempted.

According toErman Rajagukguk (1999:115), the global era is the movement of widening market, where the market is based on the competition which is sometimes unfair. The free trading can also add the gap between the developed and the third world nations, which will cause in the society composition and the live condition. In such a situation, the negotiating confirmation and the Indonesian approach in the position among 
the international countries is a strategic matter. The struggle is also needed in order that the International countries, especially the rich countries which hold the commitment to keep the development and the prosperity for the poor countries, so that it does not happen a disharmony.

The developed and rich countries, related to the stipulation in the Deed of Economic Rights and Duties of States UN General Assembly,need to carry out a real action. The aim is to make a new arrangement of the international economic more developed based on the collective interest, cooperative, similarity of sovereignty, justice and interdependence among the countries without considering the social and economic systems (Huala Adolf, 1998:143).

Indonesia, in joining to the GATT, is just for implicating the global economic wisdom system. GATT is the representation of the world commerce expansion, and also it is carried out the rate rationalization. GATT is actually the commercial inter-partner contract aimed not to treat discriminatively, protectionist in the world commercial. The agreement is carried out on the activity circles, since 1947 until the Uruguay circle (1986). It was interesting because WTO could be established succesfully and it was put into effect on January 1995.One of the agendas discussed in the GATT of Uruguay circle is the TRIPs (Trade Related Aspects of Intellectual Property Rights Including Trade in Counterfeit Goods) or the Commercial Agreement related to the Intellectual Property Right that includes the commercial of the artificial good. This agreement is aimed; to increase the protection to the Intellectual Property Right of the products traded, to guarantee the procedure of the Intellectual Property Right application which does not hamper the commercial activity, to formulate the regulation and the discipline related to the implementation of the protection to the Intellectual Property Right, and to develop the regulation principle and the International cooperative mechanism to handle the trading of good resulted from counterfeiting or Intellectual Property Right hijacking (Supanto, Sarwono, 2009: 28-30).

The Intellectual Property Right, as the representation of the system of the global economic wisdom, is very important in the commercial. Indonesia has to adapt the Intellectual Property Right system, because in the TRIPs, it has been determined the fully 
appropriated principles, it means that the country members should make a regulation related to the Intellectual Property Right which goes in line with the TRIPs determination. However, the Intellectual Property Right is actually the idea support for the trans-national factory $(\mathrm{MNc})$. But its effect can convince the smaller countries and poorer. Whatever the power is, WTO can be used to increase the deceitful profit for the developed countries. It is considered that there is a great problem in the poor country, like Indonesia, which is related to the technology mastery and the skills of the human resource, so that the competition power is defeated by the developed country in the case of the Intellectual Property Right related to the society's innovation and creativity, and also the concept of the cultural ownership toward the Intellectual Property is still communal in the society.

The law in the economic field appears in the form of modern regulation. According toDavid M. Trubek, the modern regulation, as the social process, is characterized, among others are; it is in the form of human action done on purpose, it is meant to clarify the law characteristic that is instrumental.In this case, the government makes a regulation to make the changes and attempt to realize in the reality. That is the modern law function that does not just record the behavior pattern once again existing in the society, but it should attempt to become the means to distribute the policy. It means that it creates a new condition or changes something that has existed (SatjiptoRahardjo, 1983:148). In tricking the economic life, the laws considers the internal changes of Indonesian society and the dynamics of the global society, therefore it cannot be avoided the law formation in the economic field (national) that is actually a part of the International economic law.The most specifically related matter is the Indonesian participation in the international constellation of economic organization, like WTO. In the Uruguay circle, one agreement of which is establishing the WTO, and Indonesia has become the member, it means that the WTO Agreement and its attachments have become a national law. Therefore, the Indonesian national law system, related to the existence of economic commercial, becomes the part of the international economic law, too. In connection with this, the effect of the national economic law was insisted by Normin $\mathrm{S}$. Pakpahan (1998: 42). The effect relates to the appearance and the development law fields, like the law of the Intellectual Property Right, the investment law related to the 
trading, the competition law, the law of arbiter, and the law information related to the existence of transparency principle.

Viewed from its realization, the globalization refers to the international economic regulation that now becomes very interesting. This is marked by the matter of the tendencies that the international organizations have the roles in resulting many kind of international agreements that organize the economic activities. In line with the difficulty of the relation or transaction of the international economy, it has been resulted a more complex international economic regulation. Besides, it has possibly caused an international conflict, so it is needed a regulation instrument to solve it. Finally, the national regulation system is argued related to the phenomenon appearance that, nowadays, the countries have enforced themselves to adapt their national regulations to the international economic law (Huala Adolf, 1998: 24-26). All of the WTO Agreement content has been included in the national positive law system through the ratification with UU No. 7 Tahun 1994. So, every citizen and the Indonesian corporate body that is active in the business world should obey the agreement of understanding. However, in the macro-space, the agreement substantive affects directly to the economic regulation product that is needed to be renewed and be perfected in order not to arise the law conflict that is harmful (Normin S. Pakpahan, 1998: 4). The conflict potential cannot be avoided in the country relationships. Meanwhile, Indonesia is powerless in human resources if it has to face the great and developed countries in the world. This is one of the realizations of globalization phenomena in the modern society.

\section{The Intellectual Property Right on the "Traditional Knowlegde" Protection}

One of the issues that is very interesting and is developing now in the scope of the Intellectual Property Right study is the regulation protection to the intellectual property created by the original or the traditional society. The intellectual property created by the original society includes many things, starting from the traditional knowledge, the art works, up to the one known as indigenous science and technology (Supanto, Sarwono, 2009:32-33).

The Traditional knowledgeis the new regulation problem in the field of the Intellectual Property Right which is developing in the national and international 
countries, including the World Intellectual Property Organization (WIPO). The traditional knowledge is meant as the knowledge owned or mastered and used by a community, society or a certain tribe from one generation to others and is developing continuously in accordance to the environment changes (Agus Sardjono, 2006: 1). The traditional knowledge has become the new regulation problem because there is not any domestic regulation instrument that is able to give a regulation protection optimally to the traditional knowledge that is now being used much by the party that is not responsible (Budi Agus Riswandi, M Syamsudin, 2005: 25). In the International level, this traditional knowledge has not yet become the international agreement to give the regulation protection. The regulation on the intellectual property containing in the TRIPs, at present has not been optimal yet to accommodate the intellectual property of the original / traditional society. Giving protection to the traditional knowledge becomes very important when it is faced to the characteristic and the uniqueness owned. There are some reasons why it is needed to develop the protection to the traditional knowledge, among others are the existence of the justice consideration, the conservation, the culture maintenance and the traditional practice, preventing expropriation from the party who has no right to the traditional knowledge components and the development of the interest usage of the traditional knowledge (Muhammad Djumhana, 2006: 56). The protection to the traditional knowledge plays in role positively to give the support to the society community in conserving their traditions.

Indonesia is a country which has the second biggest wealth of living resource (biodiversity) after Brazil, and has the wealthy of traditional knowledge in the various medical fields. Viewed from ecosystem point of view, Indonesia has 42 ecosystems with a great amount of various living resources ranging from ice plain and the meadow in Irian Jaya mountain up to the rainy forests in the lowland in Kalimantan. The Indonesian tradition knowledge, if it is developed continuously and is guaranteed its protection, will have a high economic value that can, of course, support the economic development in Indonesia. This can be a very good opportunity for Indonesia to use the potential value of the traditional knowledge that has been shown through many kinds of misappropriation processes by the foreign factories. The traditional term is a general term that includes expression, creativity, information, know how, which, in a special way, has a specific 
characteristic and can identify the social unit. The traditional knowledge begins to develop from year to year along with the regulation and policy innovations, like the policy on the farming development, living varieties (biological diversity), and intellectual property (Budi Agus Riswandi \& M. Syamsudin, 2005:27).

What is meant by the traditional knowledge given by the WTO is the traditional knowledge owned by the local or regional society that is given from generation to another generation. Meanwhile, Hansen and Van Fleet define the traditional knowledge as the information that the society in a certain community based on the experience or adaptation to the culture and its local surrounding which has developed from time to time and develops continuously. This knowledge usually supports the society and their culture and keeps the resource of the genital power in order to keep their community living persistence. The traditional knowledge includes the invention of living resource of the local society, animal breeding and proliferating special plant from a certain place (the local plant), and plant varieties. The knowledge is dynamic and includes the realization in integrating / combining the new kind of plant to the existed agricultural system or the new medical plant testing carried out by the traditional medical expert (Tantono Subagyo, 2005:12). Based on the definition above, it can be learned that the traditional knowledge is the identity of the local / traditional society. The traditional batik art of Tirtomoyo, Wonogiri, as the local genius of the local society, is a part of the traditional knowledge that should be protected by the regulation in accordance to the regulation stipulation of HKI. The HKI protection is related to the technology in the remukan (crushing) process as the specific characteristic of the Wonogiren batik can be registered as a simple patent. The batik design, which is resulted by the craftsman's creation, can also be included into the category of the Copyright protection, while the products of several craftsmen can also be proposed to get the brand mark registration for each traditional batik handicraft existing in Tirtomoyo, Wonogiri regency.

\section{CLOSING}

Based on the study mentioned in the chapters above, it can be concluded as follows; 
The background of using batik art on the ceremony means of the Javanese tradition in Surakarta region, in general, is suitable to the usage of each batik motive. While the variety and the batik motive usage are as follows;

Actually, it cannot be determined from where the origin of the batik making activity is. The development of batik making of the kingdom itself goes along with the development of the batik making in the outside palace society. The palace has the medium and the infrastructure, therefore batik making in the palace has better quality and more dominant thanthe development of batik making outside of the palace wall. According to SewanSusanto (1990), the batik is divided into three categories; the first category is the batik motive with divisions of geometric pattern. The batik motives among others are parang, kawung, ceplok, sidomukti, sidoluhur, sidomulyo, sido asih.

The second category is the motives with the main ornaments of plants, meru, bird or lar-laran and animals arranged in a harmony. Because it is not arranged in accordance to the geometric fields, so that it is called the "semenan" batik motive, that is semen rama, semen wijaya kusuma, gunung lar, bledag, sekar jagad, ukel, cuwiri, wahyu tumurun, gringsing, semen prabu, semen gendhong, semen nagaraja, babon angremand other motives.

The third category is the batik motive called "boketan",in which the field placement for the ornament is not the same or continuous (constant). The motive located in the full space with the various ornaments is in accordance to the batik maker's creation of every region in Tirtomoyo, Wonogiri Regency.

The development of Tirtomoyo tradition batik motive is based on the opinion resource of the local environment as the specific characteristic. They, among others, are Sandang Pangan, Catleya, Pring Sedapur, Seruni, Api Revolusi atau Smara Dahana, Lereng Api Revolusi Gringsing, andMerak. TheLereng ApiRevolusi motive is the classical batik creation of Surakarta, that is Lereng pattern, combined with Lidah Api. TheSandang Pangan andApi Revolusi orSmara Dahana motives are the ones inspirited by the event and the daily experiences. 
The symbolic meaning containing in the tradition batik motive in the ceremony of Javanese tradition in Tirtomoyo, Wonogiri, has the symbolism meanings which is accordance to the usage in the ceremony of Javanese tradition in Surakarta region and its surrounding. Actually, the symbolism itself contains philosophical value of Javanese people which is formed in accordance to the cultural frame which is magically religious.

The intellectual property right is possible to get the protection of the batik handicraft art as the "traditional knowledge" in Tirtomoyo, Wonogiri, however it contains some weakness, among others are related to the time duration of the protection, and who is the first creator due to the copyright, and the patent due to the innovation. The aspect of the Intellectual Property Right protection, when it is seen from the craftsman's point of view that runs his business, can be protected by making use of the brand mark on his service business or his products. As the art work that can be seen and touched by the five senses and enjoyed because of their beauty, the art work is protected by the regime of copyright. In the copyright, it is needed the creator who has the moral right or economic right. As the tradition that has been given from generation to generation, it cannot be known the individual that is as the creator. When there is no creator, the copyright is owned by the state, then it arises a question what if it is owned by the regional government. The making process or the dying is possibly to get the protection via the patent right. While the design can be protected by the Copyright, and the brand mark protection is given for each craftsman. In this case including the technology aspect of instruments, the mechanism of making process, also the elements containing in the color substance, if it fullfils the requirement, that is the newness, the inventive step, and it can be applied in the industry, then it can be protected by the patent. Besides, the the batik handicraft, as the the tradition work with a specific and unique feature related to the region, climate, geography, a certain ethnic, can be protected with geographical indication included in the Brand mark Regulation. The alternative attempt to protect the tradition knowledge, by still applying the existing Intellectual Property Right Regulation, is expected to be the changes in accordance to the protection of the tradition knowledge the local developing country / society. The protection can also be done by applying contract regulation. Nowadays, for its development, it is suggested to be the existence of a special regulation of the tradition knowledge. The Directorate General of the 
Intellectual Property Right, the Law and Human Right Department have now prepared the Regulation Draft on the Protection and Usage of the Intellectual Property of the Tradition Knowledge and the Expression of Traditional Culture.

The regional government policy should give the the art protection of batik handicraft as "the traditional knowledge" in Tirtomoyo, Wonogiri, based on the art potencial, trading, service, education, tourism, and sports. Here, it is drawn the purpose exactly about the development, the conservation, and the protection to the tradition knowledge as the heritage or the the culture expression, especially the traditional art. In this case, the Intellectual Property Right protection with it varieties is applied in the traditionally intellectual work. There is no confirmation about what istitutional will be responsible to the traditional knowledge, like batik, dance art, and other arts, or it involves several institutions, as a result for this the responsibility is not in one institution so that they can throw the responsibility from one to one another. Actually it will be good when they want to work together on the management of the general traditional knowledge, including the batik art related to the institution like BAPPEDA, Trading Institution, the small and medium business institution, the culture institution, and also the tourism institution. The policy on the Intellectual Property Right, especially related to the traditional knowledge, is still partial and supplement. The Industry and Trade Institutional in Wonogiri regency handles the field of the small and medium industry which is not related specifically to the industry of batik handicraft as the regional superior.

\section{BIBLIOGRAPHY:}

Agus Sardjono.2006. Potensi Ekonomi dari GRTKF; Peluang dan Hambatan dalam Pemanfaatannya: Sudut Pandang Hak Kekayaan Intelektual, Media HKI Vol. I/No.2/Februari 2005.

Anonim. 1994. Kompilasi Unndang-Undang Republik Indonesia di Bidang Hak Kekayaan Intelektual. Tangerang : Ditjen HKI Depkeh \&HAM RI dan JICA

Buchari, S., 1995, Kebudayaan Jawa, Surakarta: Universitas Sebelas Maret Press. 
Budi Agus Riswandi dan M. Syamsuddin. 2005. Hak Kekayaan Intelektual dan Budaya Hukum,. Jakarta: PT Raja Grafindo Persada.

Chadwick, C., 1972. Symbolism, London: Muthuen \& Co. Ltd.

Clare Short. 1998. The Meaningof Globalization for Development Policy, SOCIAL POLICY \& ADMINISTRATION Vol. 32 No. 5, Desember, USA: Blackwell Publisher.

Dillistone, F.W.. 1986 The Power of Symbols, London: SCM. Press Ltd..

Doellah Santosa. 2002. Batik: The Impact of Time and Environment. Surakarta: Danar Hadi.

Eddy Damian. 1999. Hukum Hak Cipta Menurut Beberapa Konvensi Internasional.Bandung: Alumni.

Erman Rajagukguk. 1999. Peranan Hukum dalam Pembangunan pada Era Globalisasi. JURNAL HUKUM No. 11 Vol. 6, Yogyakarta: UII.

Franz Magnis Suseno. 1985. Etika Jawa: Sebuah Analisa Falsafi tentang Kebijaksanaan Hidup Jawa. Jakarta : PT. Gramedia.

Hitchcock, M., 1991, Indonesian Textiles, Berkeley, Singapore: Periplus Education.

Holt, C., 1967, Art in Indonesia: Continuities and Change, Ithaca, New York: Cornell University Press

Huala Adolf.1998. HukumEkonomiInternasional. Jakarta: PT Raja Grafindo.

Igoe, Elaine,2010, DUCK Journal for Research in Textile and Textile Design "The Tacit-Turn: Textile Design in Design Research", ISSN 2042-0854 (vol.1), Leicestershire, Unite Kingdom: Loughborough University

Kalinggo Honggodipuro, KRT.2002. Batik Sebagai Busana Dalam Tatanan dan Tuntunan. Surakarta: Yayasan Peduli Karaton Surakarta Hadiningrat

Laird, Melissa, 2011, DUCK Journal for Research in Textile and Textile Design "Kraft: Making Austerity and Sleight of Hand", ISSN 2042-0854 (vol2), Leicestershire, Unite Kingdom: Loughborough University

Langer, S.K., 1963, Expressiveness and Simbolism, London: University of California Press.

Mulder, N., 1996, Pribadi dan Masyarakat Jawa, Jakarta: Sinar Harapan.

Nasikun. 2000. Globalisasi dan Problematika Pembangunan Hukum: Suatu Tinjauan Sosiologis, dalam Khudzaifah Dimyati dan Kelik Wardiono, 
Problema Globalisasi: Perspektif Sosiologi Hukum, Ekonomi, dan Agama, Surakarta: Muhammadiyah University Press.

Normin S Pakpahan. 1998. PengaruhPerjanjian WTO pada Pembentukan Hukum Ekonomi Nasional. JURNAL HUKUM BISNIS Vol.3, Jakarta: LPHB.

Prasetyo HP, 2005, "Selayang Pandang Hak Kekayaan Intelektual", Makalah, Surakarta: P3HKI UNS .

Read, H., 1970, Education Through Art, London: University of California Press.

Soedarmono, 1990, Dinamika Kultural Batik Klasik Jawa, Sarasehan Kebudayaan, Surakarta: Taman Budaya Pengembangan Batik dan Kerajinan.

Supanto,

Sarwono, 2009, InventarisasidanIdentifikasiSeniKerajinanTritikdanJumputanSebagaiTradisi di Wilayah Surakarta, Jawa Tengah KajianPengembanganKonsepHakKekayaanIntelektualdalamPerlindungan ”Traditional Knowledge”),Penelitian, Surakarta: UniversitasSebelasMaret

SatjiptoRahardjo. 1983. HukumdanPerubahanSosial. Bandung: Alumni.

SewanSusanto, S. K. 1980. Seni Kerajinan Batik Indonesia. Jakarta : Balai Penelitian Batik dan Kerajinan, Lembaga Penelitian dan Pendidikan Industri, Departemen Industri RI.

Sri Redjeki Hartono. 2007. Hukum Ekonomi Indonesia, Malang: Bayu Media.

Tantono Subagyo . 2005. Meraih Masa Depan Bermodalkan Kekayaan Masa Lalu (Perlindungan Dan Pengembangan Sumber Daya Genetika, Pengetahuan Tradisional Dan Ekspresi Folklore Di Negara-Negara ASEAN,. Media HKI, Vol. II/No.5/Oktober 2005.

Whitehead, A.N. 1928. Symbolism. Cambridge: Cambridge University Press. 